\title{
FURTHER CHARACTERIZATION OF RENNIN ACTION ON $\kappa$-CASEIN USING CARBOXYMETHYLCELLULOSE: EFFECTS OF VARIOUS ADDITIVES ON THE ENZYMATIC HYDROLYSIS OF $\kappa$-CASEIN
}

\author{
Masao Kanamori, Fumio IbUki, Hiroshi DoI, \\ Chang-Hoon Yoon, ${ }^{1}$ Takiko Yawata, ${ }^{2}$ Yöichi Hamaguchi, \\ and Masamitsu MrYosHI ${ }^{3}$ \\ ${ }^{1}$ Department of Agricultural Chemistry, Kyoto Prefectural University, \\ Kyoto 606 \\ ${ }^{2}$ Department of Home Economics, Nara Saho Women's College, \\ Nara 630 \\ ${ }^{3}$ Department of Food Science and Nutrition, Nara Women's University, \\ Nara 630 \\ (Received October 14, 1976)
}

\begin{abstract}
Summary The effects of various additives on the reaction of rennin with $\kappa$-casein were investigated by using carboxymethylcellulose. Both urea and sodium 1-anilino-8-naphthalenesulfonate effectively inhibited rennin action at concentrations larger than $2 \mathrm{M}$ and $2 \mathrm{~mm}$, respectively. These reagents, however, activated the enzyme action at the lower concentrations. Both $\alpha_{\mathrm{s}^{-}}$and $\beta$-caseins had some ranges of concentrations in which the rennin reaction was activated. Calcium chloride had an inhibitory effect on the rennin action. Neither mercaptoethanol nor $\mathrm{KCl}$ had any appreciable effect on the enzymatic hydrolysis of $\kappa$-casein. These results are analyzed in terms of the association and dissociation of $\kappa$-casein due to the presence of these additives in the reaction solutions.
\end{abstract}

Misleading results will be unavoidable in rennin assays based on the secondary reaction, the coagulation of casein brought about by rennin, when some substances other than the substrate is added to the reaction mixture. The coagulation is very sensitive to the slightest changes in reaction conditions, such as additives, temperature, $\mathrm{pH}$, ionic strength and even reaction time. For this reason, it is only possible to investigate effects of additives on rennin reaction by measuring its primary phase, the hydrolysis of $\kappa$-casein between phenylalanine and methionine (1). The cleavage of this bond results in the formation of two peptides, macropeptide

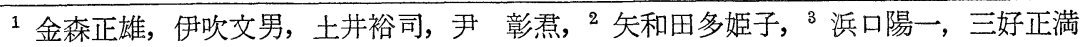


and para- $\kappa$-casein (2). The macropeptide contains all the carbohydrate components of $\kappa$-casein the composition of which is not homogeneous $(3,4)$. Macropeptide rich in carbohydrate is more soluble in a trichloracetic acid (TCA) solution than that poor in carbohydrate. Furthermore, it is devoid of aromatic amino acids (5) and must be determined from the nitrogen content by using the timeconsuming Kjeldahl method. In these regards, it is not always easy to estimate rennin reaction by measuring the macropeptide released by rennin. On the contrary, para- $\kappa$-casein is always homogeneous and can be easily determined from ultraviolet (UV) light absorption. It is a uniquely basic protein with a pI of $9.2(6)$. Considering this property of para- $\kappa$-casein, we previously developed a new method for measuring rennin reaction based on the removal of para- $\kappa$-casein from the reaction mixture by adsorbing it exclusively to carboxymethylcellulose (CM-cellulose) (7). The basic properties of the rennin reaction with $\kappa$-casein were previously reported (8). The present paper describes the effects of various additives on the rennin action on $\kappa$-casein which have been difficult to elucidate without ambiguity by conventional methods.

\section{METHODS}

Preparation of $\kappa-, \alpha_{\mathrm{s}}-$, and $\beta$-caseins. $\kappa$-Casein and $\alpha_{\mathrm{s}}$-casein, and $\beta$-casein were prepared by the methods of ZITTLE and Custer (9), and of Hipp et al. (10), respectively.

Assay method. The previous method was slightly modified in the concentration of urea used to terminate the reaction. The reaction was started by adding $0.01 \mathrm{ml}$ of $0.1 \%$ rennin solution in $0.01 \mathrm{M}$ Tris- $\mathrm{HCl}$ buffer, $\mathrm{pH} 7.0$, to $0.1 \mathrm{ml}$ of $2 \% \kappa$-casein solution in the same buffer that had been mixed with $0.1 \mathrm{ml}$ of the solutions of various additives prepared in the same buffer. Both the rennin and the $\kappa$-casein solutions had been kept in a reaction bath for $5 \mathrm{~min}$ before the reaction started. The reaction was carried out for $5 \mathrm{~min}$ at $30^{\circ} \mathrm{C}$ and terminated by adding $1.9 \mathrm{ml}$ of $0.01 \mathrm{M}$ Tris-citrate buffer, $\mathrm{pH} 7.7$, containing $6 \mathrm{M}$ urea, $0.3 \%$ mercaptoethanol and $20 \mathrm{mg}$ CM-cellulose. The whole mixture was kept in ice with occasional shaking until it was centrifuged for the UV absorption measurement of the supernatant solution. The hydrolysis rate of $\kappa$-casein was calculated as described previously (7).

Addition of various substances to the reaction mixtures. $\kappa$-Casein solutions $(2 \%)$ were prepared in $0.01 \mathrm{M}$ Tris- $\mathrm{HCl}$ buffer, $\mathrm{pH} 7.0$, containing $0.25,0.50,0.75$, $1,2,3,4,5,6,7$, and $8 \mathrm{M}$ urea. $\mathrm{KCl}$ and $\mathrm{CaCl}_{2}$ solutions were prepared at concentrations of $0,20,40$, and $60 \mathrm{mM}$. A $2 \% \kappa$-casein solution $(0.1 \mathrm{ml})$ in $0.01 \mathrm{M}$ Tris- $\mathrm{HCl}$ buffer, $\mathrm{pH} 7.0$, had been mixed with equal volume of each of these solutions and the mixture was kept at $37^{\circ} \mathrm{C}$ for $5 \mathrm{~min}$ before the reaction started. Mercaptoethanol solutions were prepared at concentrations of $0,0.4,0.8,1.2$, $1.6,2.0,3.0$, and $4.0 \%$. A $2 \% \kappa$-casein solution $(0.1 \mathrm{ml})$ in $0.01 \mathrm{M}$ Tris- $\mathrm{HCl}$ buffer, 
$\mathrm{pH} 7.0$, was mixed with equal volume of each solution and the reduction of $\kappa$ casein was carried out at $0^{\circ} \mathrm{C}$ for $30 \mathrm{~min}$. Sodium 1-anilino-8-naphthalene-sulfonate (ANS) solutions were prepared at concentrations of $1,2,3,4,6,8$, and $10 \mathrm{~mm}$. A $\kappa$-casein solution $(0.1 \mathrm{ml})$ mixed with each of these solutions $(0.1 \mathrm{ml})$ was preincubated at $37^{\circ} \mathrm{C}$ for $10 \mathrm{~min}$ before starting the rennin reaction. The reaction was terminated as described above and the whole mixture was centrifuged. The absorption at $280 \mathrm{~nm}$ was too high because of the presence of ANS in the supernatant solution. For this reason, the supernatant solution was discarded and the remaining CM-cellulose was washed three times with a total volume of $6 \mathrm{ml}$ of $0.01 \mathrm{~m}$ Tris-citrate buffer, $\mathrm{pH} 7.7$, containing $6 \mathrm{M}$ urea. Then, the para- $\kappa$-casein bound by the CM-cellulose was eluted with $2 \mathrm{ml}$ of $0.01 \mathrm{M}$ Tris-citrate buffer, pH 7.7, containing $6 \mathrm{M}$ urea, $0.3 \%$ mercaptoethanol and $0.5 \mathrm{M} \mathrm{NaCl}$. The entire eluate was centrifuged and the absorption at $280 \mathrm{~nm}$ of the supernatant was measured. Solutions of $\alpha_{\mathrm{s}}$ - and $\beta$-caseins were prepared in $0.01 \mathrm{M}$ Tris- $\mathrm{HCl}$ buffer, $\mathrm{pH} 7.0$, at the concentrations of $0,0.4,0.8,1.2,1.6,2,4,6,8,10 \%$. A $2 \%$ $\kappa$-casein solution $(0.1 \mathrm{ml})$ in $0.01 \mathrm{M}$ Tris- $\mathrm{HCl}$ buffer, $\mathrm{pH} 7.0$, was mixed with $0.1 \mathrm{ml}$ of each of the above solutions and each mixture was incubated at $37^{\circ} \mathrm{C}$ for $10 \mathrm{~min}$ before starting the reaction. Similar assays were carried out in the presence of $5 \mathrm{~mm}$ and $20 \mathrm{mM} \mathrm{CaCl}_{2}$. The $8 \%$ and the $10 \% \beta$-casein solutions produced large amounts of precipitate on addition of calcium ions and were not subjected to analysis. The reactions were followed by measurement of the UV light absorption due to para- $\kappa$-casein which was eluted out of CM-cellulose as described in the case of ANS.

\section{RESULTS}

Figure 1 shows how the presence of various concentrations of urea in the $5 \mathrm{~min}$ reaction mixture affected the hydrolysis of $\kappa$-casein by rennin. The presence of $2 \mathrm{M}$ urea or less seems to increase the hydrolysis rate slightly. The presence of more than $2 \mathrm{M}$ urea, however, apparently inhibited the enzyme action. Neither 3 nor $4 \mathrm{M}$ urea was sufficient to prevent the enzymatic hydrolysis of $\kappa$-casein completely. The concentration of $5 \mathrm{~m}$ seems to be the turning point at which rennin activity is reduced to a negligible level. $\mathrm{KCl}$, in the concentrations up to $30 \mathrm{~mm}$, had no effects on the rennin action as shown in Fig. 2. On the contrary, $30 \mathrm{~mm}$ $\mathrm{CaCl}_{2}$ inhibited the hydrolysis of $\kappa$-casein by $50 \%$. The effect of mercaptoethanol was not significant when it was present in the reaction mixture up to the concentration of $2 \%$ (Fig. 3). The addition of ANS activated the hydrolysis of $\kappa$-casein at concentrations lower than $1.5 \mathrm{~mm}$ at which the para- $\kappa$-casein formation reached a peak, $150 \%$ of the control (Fig. 4). The reaction rate, however, began to slow down almost linearly when the concentration exceeded $1.5 \mathrm{~mm}$ and finally dropped to zero in the presence of $5 \mathrm{mM}$ ANS. The effect of $\alpha_{\mathrm{s}}$-casein on the rennin action was rather striking (Fig. 5). Regardless of the presence or absence of $\mathrm{CaCl}_{2}$, the hydrolysis of $\kappa$-casein was activated by $\alpha_{\mathrm{s}}$-casein, when the amounts of $\alpha_{\mathrm{s}}$-casein 


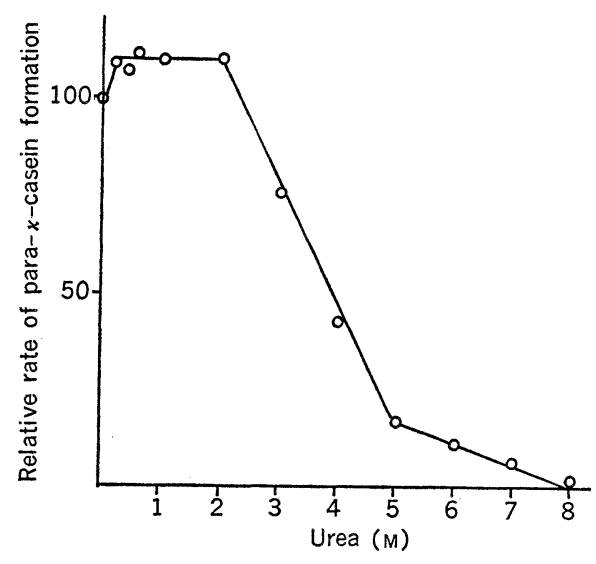

Fig. 1.

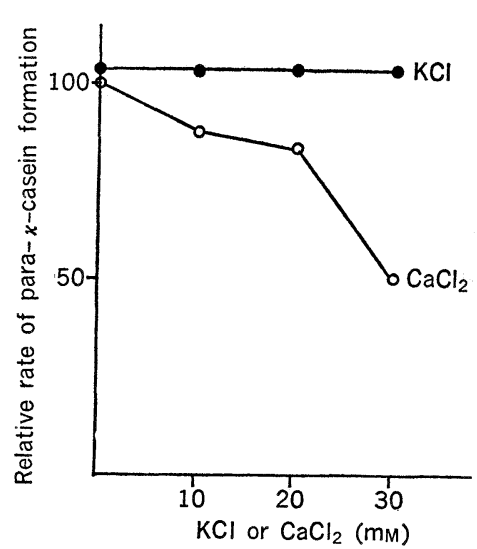

Fig. 2.

Fig. 1. Effect of urea on the rennin activity.

Fig. 2. Effects of $\mathrm{KCl}$ and $\mathrm{CaCl}_{2}$ on the rennin activity.

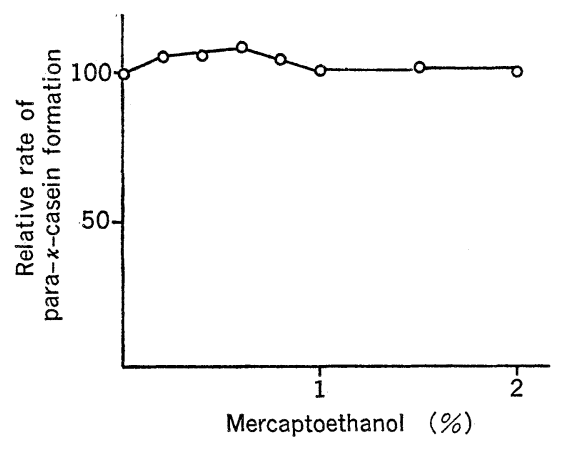

Fig. 3.

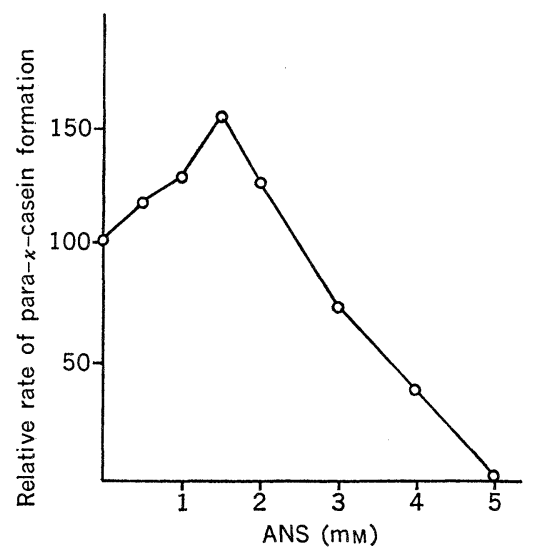

Fig. 4.

Fig. 3. Effect of mercaptoethanol on the rennin activity.

Fig. 4. Effect of sodium 1-anilino-8-naphthalenesulfonate on the rennin activity.

were less than those of $\kappa$-casein. The highest rate reached 160 to $200 \%$ of the control. The presence of larger amounts of $\mathrm{CaCl}_{2}$ seems to make the activation more prominent. When the amounts of $\alpha_{\mathrm{s}}$-casein exceeded those of $\kappa$-casein, however, such activation disappeared and the hydrolysis rates stayed almost constant, as high as those obtained without $\alpha_{\mathrm{s}}$-casein. The rennin reaction was also remarkably activated by $\beta$-casein (Fig. 6). The activation patterns are, however, somewhat different from those obtained with $\alpha_{\mathrm{s}}$-casein. No sharp peaks of activation were obtained even when three times as much $\beta$-casein was added as $\kappa$-casein. In addition, the presence of larger amounts of $\mathrm{CaCl}_{2}$ increased the 


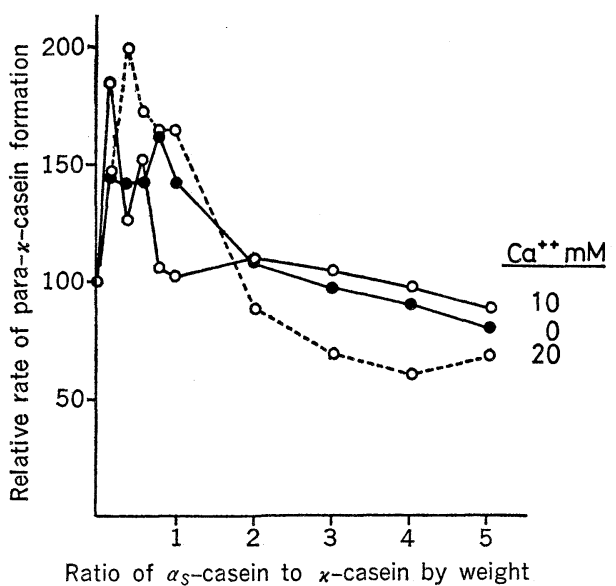

Fig. 5.

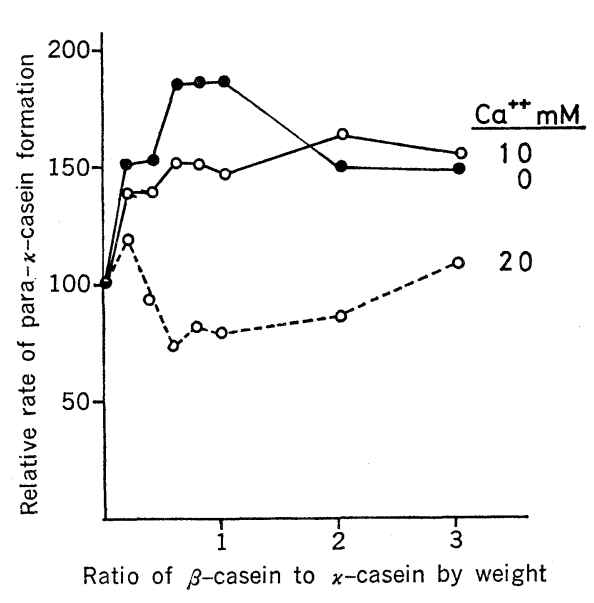

Fig. 6.

Fig. 5. Effects of $\alpha_{\mathrm{S}}$-casein on the hydrolysis of $\kappa$-casein by rennin.

Fig. 6. Effects of $\beta$-casein on the hydrolysis of $\kappa$-casein by rennin.

reaction rate to $186 \%$ of the control with $1: 1$ ratio of $\beta$ - to $\kappa$-casein. The activation reached $163 \%$ with $2: 1$ ratio in the presence of $5 \mathrm{~mm} \mathrm{CaCl}_{2}$. The results obtained in the presence of $20 \mathrm{mM} \mathrm{CaCl}_{2}$ were not consistent mainly because of the instability of the $\beta-\kappa$ complex under these conditions.

\section{DISCUSSION}

Since casein is one of the most easily associable proteins through the electrostatic, hydrophobic and S-S interactions, casein molecules should be dissociated by an alkaline buffer containing urea and mercaptoethanol in order to estimate each species of casein. These dissociating agents simultaneously play the role of terminating the enzymatic reaction. In the present experiment it was found that rennin reaction was not stopped completely by the presence of $4 \mathrm{M}$ urea only. The concentration must be increased to $6 \mathrm{M}$ or higher, or the temperature be lowered to $0^{\circ} \mathrm{C}$ for the complete termination. The only limiting factor to be considered in our assay method is the possible disturbance of the binding of para- $\kappa$-casein to CM-cellulose by additives. Therefore, the concentrations of any additives were carefully chosen in the present experiment so that their presence in the assay mixtures might not lead to incorrect results. It was found quite satisfactory to elute para- $\kappa$-casein once bound to CM-cellulose for measuring its UV light absorption, when the supernatant solution obtained by centrifuging CM-cellulose that had bound para- $\kappa$-casein contained too much substance with the ability to absorb UV light, as in the cases of $\alpha_{\mathrm{s}}$-casein, $\beta$-casein and ANS. This elution method should be also applicable to the rennin assay with whole casein as the substrate. 
The slight increase of para- $\kappa$-casein formation in the presence of $2 \mathrm{M}$ urea or less is probably due to the dissociation of $\kappa$-casein complexes which are assumed to be composed of about 40 molecules (11). As the concentration of urea increased, however, the enzyme denaturation became more critical and the reaction began to be inhibited. The effect of ANS can be interpreted in a similar way. It was suggested that small amounts of ANS caused dissociation of $\kappa$-casein complexes whereas larger amounts would not (12) and instead might cause some conformational change in the rennin structure. The insignificant effect of mercaptoethanol indicates that $\mathrm{S}-\mathrm{S}$ bonds play a less important role in the maintenance of $\kappa$-casein complexes than hydrophobic interaction. The presence of $\mathrm{CaCl}_{2}$ caused aggregation of $\kappa$-casein complexes and therefore inhibited the rennin action on $\kappa$-casein. The results of addition of $\alpha_{\mathrm{s}}$ - and $\beta$-caseins to the reaction mixtures are interesting, but they are difficult to interpret in detail. The stimulatory effects seem to indicate that the $\kappa$-casein complexes are stretched out and located outside the artificial micelles when the complexes interact with small amounts of these caseins. When the micelles become larger due to the presence of larger amounts of $\alpha_{\mathrm{s}}$ - or $\beta$-casein, or calcium ions, the susceptibility of $\kappa$-casein to rennin seems to decrease. It had been expected before the experiment started that the reaction would be retarded by the presence of $\alpha_{\mathrm{s}}$ - and $\beta$-caseins and that such retardation would level off when the amounts of these caseins exceeded those necessary for the formation of complexes with $\kappa$-casein. It is generally admitted that the micelle is formed with the 1:1 ratio of $\alpha_{\mathrm{s}}$ - and $\kappa$-caseins in the absence of $\mathrm{Ca}^{2+}$ and with the higher ratios in the presence of $\mathrm{Ca}^{2+}(13)$. However, the hydrolysis rate of $\kappa$-casein in such micelles came down to a constant level with the $2: 1$ ratio even in the presence of $20 \mathrm{mM} \mathrm{CaCl}_{2}$. The reasons for the unexpected results are not clear at present. Preliminary experiments clearly indicated that neigher $\alpha_{\mathrm{s}}$-casein nor $\beta$-casein were attacked by rennin during the $5 \mathrm{~min}$ of incubation which is too short for the third phase of rennin reaction to occur.

\section{REFERENCES}

1) Jollés, J., Jollés, P., and Alais, C. (1969): Present knowledge concerning the amino acid sequence of cow $\kappa$-casein. Nature, 222, 668-670.

2) Delfour, A., Jollés, J., Alais, C., and Jollés, P. (1965): Caseinoglycopeptides; characterization of a methionine residue and of the N-terminal sequence. Biochem. Biophys. Res. Commun., 19, 452-455.

3) Mackinlay, A. G., and Wake, R. G. (1965): Fractionation of S-carboxymethyl- $\kappa$-casein and characterization of the components. Biochim. Biophys. Acta, 104, 167-180.

4) Armstrong, C. E., Mackinlay, A. G., Hill, R. J., and Wake, R. G. (1967): The action of rennin on $\kappa$-casein: The heterogeneity and origin of the soluble product. Biochim. Biophys. Acta, 140, 123-131.

5) Kuwata, T., Niki, R., and Arima, S. (1969): Studies on the action of rennin on casein, Composition and properties of glyco-macropeptides from $\kappa$-casein. Nippon Nōgeikagaku Kaishi (J. Agric. Chem. Soc. Jap.), 43, 183-188.

6) Miyoshi, M., IbuKi, F., KanAmori, M., and MaKi, Z. (1971): Reduced components and $\alpha_{\mathrm{s}^{-}}$ 
casein stabilizing ability of succinylated $\kappa$-casein. Eiyo To Shokuryo (J. Jpn. Soc. Food Nutr.), 24, 269-274.

7) Mryoshi, M., Yoon, C. H., Ibuki, F., and Kanamori, M. (1975): New methods for the determination of rennin activity with $\kappa$-casein. J. Nutr. Sci. Vitaminol., 21, 309-312.

8) Mryoshi, M., Yoon, C. H., IbUKI, F., and Kanamori, M. (1976): The characterization of rennin action on $\kappa$-casein using CM-cellulose. Agric. Biol. Chem., 40, 347-352.

9) ZitTLE, C. A., and Custer, J. H. (1963): Purification and some of the properties of $\alpha_{\mathrm{s}}$-casein and $\kappa$-casein. J. Dairy Sci., 46, 1183-1188.

10) Hipp, N. J., Grove, M. L., and McMeekin, T. L. (1952): Acid-base titration, viscosity and density of $\alpha$-, $\beta$ - and $\gamma$-casein. J. Amer. Chem. Soc., 74, 4822-4826.

11) Kaminogawa, S., Dosako, S., and Yamauchi, K. (1974): Studies on molecular properties of $\alpha_{\mathrm{s} 1}-\kappa$-casein complex by the hydrodynamical methods. Agric. Biol. Chem., 38, 23372341.

12) Sugimoto, E., Yoshikawa, M., Nishida, Y., and Chiba, H. (1974): Effect of 1-anilino-8naphthalenesulfonate on properties and associations of $\alpha_{\mathrm{s}}-, \beta$ - and $\kappa$-caseins. Agric. Biol. Chem., 38, 2497-2504.

13) Garnier, J., Yon, J., and Mocquot, G. (1964): Contribution a l'etude de l'association entre la caseine $\kappa$ et la caseine $\alpha_{\mathrm{s}}$ a pH neutre. Biochim. Biophys. Acta, 82, 481-493. 